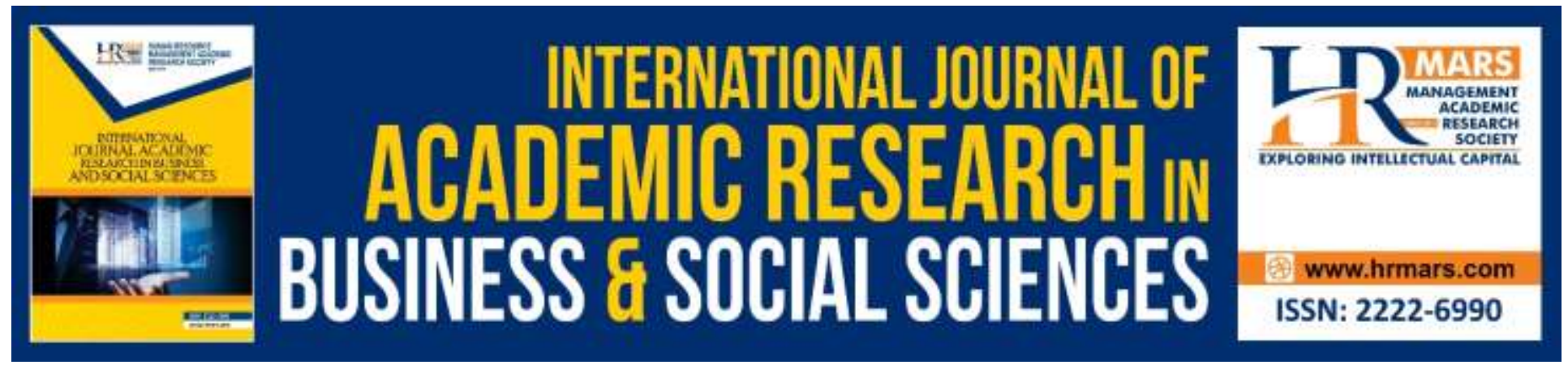

\title{
Islamic-Based Development Focus in the Mission Statements of Islamic Institutions in Malaysia
}

\author{
Farah Farhana Johari, Fadzila Azni Ahmad
}

To Link this Article: http://dx.doi.org/10.6007/IJARBSS/v9-i11/6590

DOI: 10.6007/IJARBSS/v9-i11/6590

Received: 10 September 2019, Revised: 20 October 2019, Accepted: 05 November 2019

Published Online: 27 November 2019

In-Text Citation: (Johari, Ahmad, 2019)

To Cite this Article: Johari, F. F., Ahmad, F. A. (2019). Islamic-Based Development Focus in the Mission Statements of Islamic Institutions in Malaysia. International Journal of Academic Research in Business and Social Sciences, 9(11), 685-694.

Copyright: (C) 2019 The Author(s)

Published by Human Resource Management Academic Research Society (www.hrmars.com)

This article is published under the Creative Commons Attribution (CC BY 4.0) license. Anyone may reproduce, distribute, translate and create derivative works of this article (for both commercial and non-commercial purposes), subject to full attribution to the original publication and authors. The full terms of this license may be seen

at: $\underline{\text { http://creativecommons.org/licences/by/4.0/legalcode }}$

$$
\text { Vol. 9, No. 11, 2019, Pg. } 685 \text { - } 694
$$

Full Terms \& Conditions of access and use can be found at http://hrmars.com/index.php/pages/detail/publication-ethics 


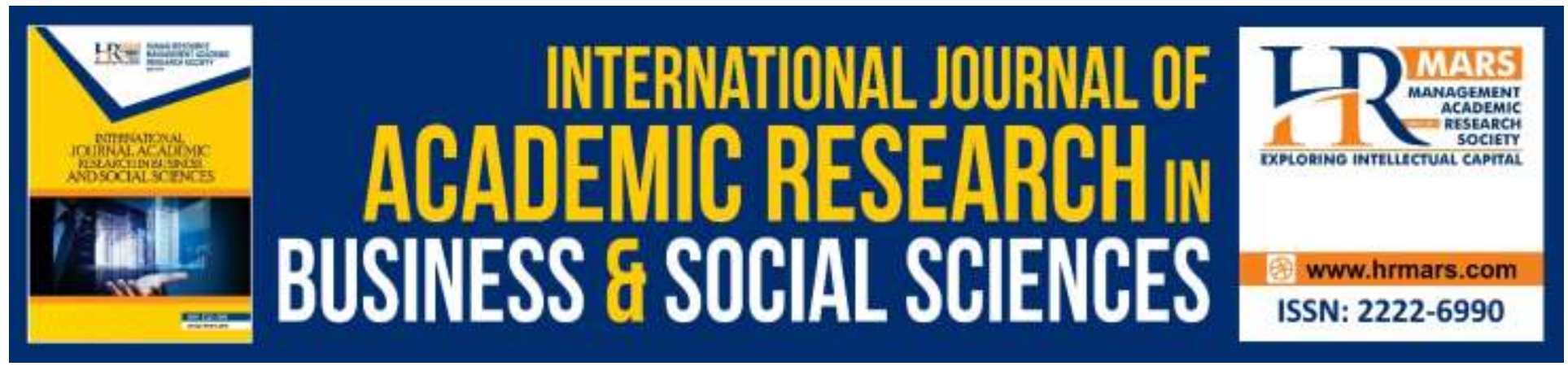

\title{
Islamic-Based Development Focus in the Mission Statements of Islamic Institutions in Malaysia
}

\author{
Farah Farhana Johari, Fadzila Azni Ahmad \\ Centre for Islamic Development Management Studies (ISDEV), Universiti Sains Malaysia, \\ Penang, Malaysia
}

\begin{abstract}
Islamic-based development institutions (IBD) play a pivotal role in fulfilling the aim and direction of Islamic-based development. Towards this effort, the mission statement is adopted as the tool to clarify this. Almost all of the IBD institutions also exhibit their missions very clearly through their official websites and annual reports. It raises a question, is it the mission statement really fulfills the aim and direction of IBD? Thus, this article seeks to focus on the mission statements of IBD institutions. The focus of discussion involves selected 89 IBD institutions in Malaysia. For this purpose, this article also performs content analysis on the secondary data that have been obtained. Apart from that, the analysis also focusing on the Islamic aspect is also carried out by considering nine important components of the mission statement that are often outlined by practitioner and academicians in the strategic management field. Our observation reveals that the aim and direction of IBD are not really fulfilled. The aim and direction emphasized by the IBD are more directed towards conventional development.
\end{abstract}

Keywords: Mission Statement, Strategic Management, Islamic-Based Development Management, Islamic Management, Islamic Quality Management.

\section{Introduction}

In general, every establishment of the institutions will have its own aim and direction, and this includes IBD institutions. IBD institutions is an institution that strives to fulfill the aim of Islamicbased development, although not comprehensively (Ahmad, 2010; Lokman, Yusoff, Khalid, \& Nasri, 2018). At this point, Omar (1996:136) asserts that Islamic organizations transform and manage the work culture and management practice based on the Islamic management system. In reality, there are several characteristics that distinguish IBD institutions from conventional institutions. As outlined by Azid, Asutay and Burki (2007) Islamic organizations are prohibited from manufacturing illegal products, increasing the manufacturing of quality goods and reducing the amount of luxurious goods and obeying the Islamic principles which are to make moderate 
profits. Based on the definition, method of management and the characteristics stated, IBD needs to be different from the conventional ones. Due to this, the aim and direction outlined through the mission statement of IBD institutions should have a different emphasis compared to the conventional institutions.

Realistically, mission statement is present together with the vision statement. However, both these statements carry different meanings. The vision statement refers more to the depiction of aim that is to be achieved, whereas the mission statement elaborates on the aim very clearly (Rothaermel, 2015). Rothaermel (2015); Jaradat, (2018) also states that mission statement explains the reality given by the organization which is the plan to prepare products, services and competition in the market. Gamble, Peteraf dan Thompson (2016) next, state that most organizations explain about the scope and the latest purpose through their mission statement, such as who are they? What do they do? And why are they there? Unlike vision statement, mission statement is capable of determining the current and future types of business (Hashim, 2008; Mavridis \& Mouratidou, 2019). To add, mission statement developed based on the vision statement is very much needed to help answer the question, what is the business of the organization? What does an organization do? (Hashim, 2008). This is not improbable, as Hanson, Dowling, Hitt, Ireland and Hoskisson (2008) used to make this assertion that a mission statement is more concrete than a vision statement.

On the same token, mission statement is seen to be clearer when it comes to elaborating on the aim and direction of the institution in further detail. A clear mission statement is important as it creates objectives and formulates strategies (David, 1993). Thus, this article discusses the aim and direction of IBD institutions by giving focus onto the mission statement of IBD institutions. For the purpose of discussion, this article analyses nine important components that are often outlined by academicians and practitioners of strategic management field in formulating mission statements. The nine components comprise of philosophy, customer, service, market, technology, profit, image, employee and efficiency. These components have been stressed in the works of David and David (1989; 1996; 2001; 2003; 2006; 2011), Pearce (1982), Pearce and David (1987), Pearce and Roth (1988), Strong (1997), Analoui and Karami (2002), Rezvani and Akhbarzadeh (2010), Haghighi et. al (2010), Moin, Ali and Khan (2012), Azizi and Hosseinabadi (2014) and Gamble, Peteraf, and Thompson (2016).

\section{Methods}

This article adopts an exploratory study. This study is done to identify the mission statement of IBD institutions in Malaysia. Other than that, this study also involves the secondary data collection. The secondary data collection method is done by carefully looking into the mission statement exhibited through the websites and annual reports shown by selected IBD institutions in Malaysia. As this study involves the main IBD institutions only, the purposive sampling technique used aims to identify the main IBD institutions in Malaysia. In relation, this study chooses 89 main IBD institutions in Malaysia as a sample. Next, the data obtained is analysed 
using the content analysis method. To achieve data accuracy in the form of statistical frequency, this article also uses the SPSS software (Statistical Package for the Social Sciences).

\section{Discussion}

Rooting from the issue that emerges, this article identifies the components of the mission statement outlined by the IBD institutions in Malaysia. This observation involves nine components (philosophy, customer, service, market, technology, profit, image, employee and efficiency) that are effective to develop this mission statement. According to David (1993:102), seeing that the mission statement comprises of nine important things in strategic management, to process it would require all nine components. Table 1 generally displays the number and percentage of IBD institutions that account for the components in its mission statement.

Table 1: General Components of the Institution's Mission Statement

\begin{tabular}{|c|c|c|c|c|c|c|c|}
\hline \multirow{2}{*}{ Component } & \multicolumn{2}{|c|}{ Present } & \multicolumn{2}{|c|}{ Not Present } & \multicolumn{2}{|c|}{ No Mission } & \multirow{2}{*}{$\begin{array}{l}\text { Total (\%) } \\
\mathrm{N}=89\end{array}$} \\
\hline & Num. & $\%$ & Num. & $\%$ & Num. & $\%$ & \\
\hline Philosophy & 69 & 77.5 & 5 & 5.6 & 15 & 16.9 & 100 \\
\hline Customer & 19 & 21.3 & 55 & 61.8 & 15 & 16.9 & 100 \\
\hline Services & 58 & 65.2 & 16 & 18.0 & 15 & 16.9 & 100 \\
\hline Market & 22 & 24.7 & 52 & 58.4 & 15 & 16.9 & 100 \\
\hline Technology & 14 & 15.7 & 60 & 67.4 & 15 & 16.9 & 100 \\
\hline Profit & 5 & 5.6 & 69 & 77.5 & 15 & 16.9 & 100 \\
\hline Image & 4 & 4.5 & 70 & 78.7 & 15 & 16.9 & 100 \\
\hline Employee & 11 & 12.4 & 63 & 70.8 & 15 & 16.9 & 100 \\
\hline Efficiency & 30 & 33.7 & 44 & 49.4 & 15 & 16.9 & 100 \\
\hline
\end{tabular}

Table 1 above portrays the findings related to the institution's mission statement in general. It can be seen that IBD institutions prefer their own philosophies besides laying importance to 'services' instead of clients. The findings show that 69 institutions (77.5\%) mentioned the 'philosophy' component and this figure was the highest compared to the other components. Based on this figure, it could be said that almost all institutions in the study had placed 'philosophy' as their actual objective and 'organizational purpose' (direction). The analysis also found that 'philosophy' was emphasized by all types of institutions in this study.

In line with the 'philosophy' mentioned earlier, the institution's promise to offer services has never been neglected when setting its objective. 'Services' had the highest figure after 'philosophy' with 58 institutions (65.2\%). Hence, it was found that not all types of institutions involved had promised 'services' when developing their institutions. Institutions involved in worship, administration, finance, medical services and legal matters were among the type of institutions that promised 'services' in their mission statements. 
Actually, Manda (2013) had argued about 'services' from a Western perspective by saying that 'services' form the fundamental elements that connect an institution with the client. According to the author, client satisfaction is an alternative that develops an institution's renowned status. This opinion does somewhat influence the institution's development. Another finding showed that the IBD institutions in this study were not exempted from adopting the conventional concept as a short-term objective. This was because the institution's focus on the 'services' component had the highest score in the findings.

After 'services', the institution's 'efficiency' was the next focus when developing an institution. It was found that 30 institutions (33.7\%) promised 'efficiency' as part of the 'organizational purpose (direction). In addition, 'efficiency' was the focal point of all the institutions that were studied because all these institutions had mentioned 'efficiency' in their mission statements. Next, only $22(24.7 \%)$ institutions had made 'market' as one its focus in this study. 'Market' here refers to the whole market, including the Islamic market. The majority of institutions that focused on the 'market' were institutions related to education, administration and banking.

Next, were components that recorded the lowest number and percentage $19(21.3 \%)$ institutions had focused on 'clients', 14 (15.7\%) had focused on 'technology', 11 (12.4\%) had focused on 'employees', 5 (5.6\%) had focused on 'profit' and only 4 (4.5\%) focused on 'image'. These findings indirectly show that a large number of institutions in this study had focused on 'philosophy', besides promising an efficient 'service'. Examples of institutions whose mission statements portray 'philosophy', 'service' and 'efficiency' are Department of Awqaf, Zakat and Hajj (JAWHAR) and Majlis Agama Islam Selangor (MAIS). The mission statements sound something like this,

"Improve the socio-economic development through the strengthening of community institutions of Awqaf, Zakat, Mal and Hajj/Umrah through governance and service delivery system (JAWHAR, 2018).

"To develop social and economic ummah in the state of Selangor in enhancing Islamic Shari'ah" (MAIS, 2018)

However, the research was very general in nature. If the research were carried out in an Islamic context, would 'philosophy' and 'services' be the institution's main focus? If true, would the 'philosophy' mentioned by the IBD institution be more inclined to Islamic philosophy? Hence, Table 2 below shows the findings based on Islam. 
INTERNATIONAL JOURNAL OF ACADEMIC RESEARCH IN BUSINESS AND SOCIAL SCIENCES

Vol. 9, No. 11, November, 2019, E-ISSN: 2222-6990 @ 2019 HRMARS

Table 2: Islamic-based Components in the Institution's Mission Statement

\begin{tabular}{llllllll}
\hline \multirow{2}{*}{ Components } & \multicolumn{2}{l}{ Present } & \multicolumn{2}{l}{ Absent } & \multicolumn{2}{l}{ No Mission } & Total (\%) \\
& Num. & \% & Num. & \% & Num. & \% & N=89 \\
\hline Philosophy & 41 & 46.1 & 33 & 37.1 & 15 & 16.9 & 100 \\
Customer & 10 & 11.2 & 64 & 71.9 & 15 & 16.9 & 100 \\
Services & 30 & 33.7 & 44 & 49.4 & 15 & 16.9 & 100 \\
Market & 8 & 9.0 & 66 & 74.2 & 15 & 16.9 & 100 \\
Technology & 3 & 3.4 & 71 & 79.8 & 15 & 16.9 & 100 \\
Profit & 12 & 13.5 & 62 & 69.7 & 15 & 16.9 & 100 \\
Image & 2 & 2.2 & 72 & 80.9 & 15 & 16.9 & 100 \\
Employees & 1 & 1.1 & 73 & 82.0 & 15 & 16.9 & 100 \\
Efficiency & 16 & 18.0 & 58 & 65.2 & 15 & 16.9 & 100 \\
\hline
\end{tabular}

'Philosophy' in a development context here consists of 'motivation', 'method' and 'organizational purpose' (direction). Islamic development philosophy is based on important fundamentals such as rububiah (divinity), khalifah (vicegerent of God) and al-falah (success) (Manan, Kasan \& Bahall, 2013). Therefore, philosophy component in this section was studied based on the views of these three writers.

Hence, research in the Islamic context (Table 2) found that 'philosophy' and 'services' were still the focus in efforts to achieve the objectives of an IBD institution compared to other components. This is evident when $41(46.1 \%)$ institutions stated that 'philosophy' was their main objective. Meanwhile, 30 (33.7\%) institutions stated that 'service' was their main objective. This was the highest figure recorded compared to other components. Among the institutions that had an Islamic-based focus on all three components were institutions related to worship, administration, education, banking, socio-economy, finance and law.

In relation to this issue, it is evident that philosophy is a significant element in achieving the objectives of IBD institutions. This is due to the institution's focus that emphasises IBD philosophy in order to achieve its objectives. According to Al-Kindi based from an exerpt from Jimale (2012), philosophy works on the human mind to achieve reality, either in the fields of metaphysics, morality or values (axiology) or ma'rifah (epistemology). In the context of this research, philosophy is about thinking or ideas that help achieve the IBD institution's objectives. This thinking or idea, which is created by the institution's mission statement that acts as the objective and direction, is what should be achieved.

Besides that, 30 (33.7\%) IBD institutions gave priority to Islamic services when seeking to achieve their objectives. These institutions were related to worship, administration, banking, socioeconomy, finance and law. However, for the other seven components, only a few institutions 
that were studied had included these components in their mission statements. The total number and the percentage referred to was approximately $18.0 \%$ to $1.1 \%$ of the institutions. Based on this finding, it clearly shows that IBD institutions do not emphasize on other components as the objective, besides the 'philosophy' and 'services'.

However, based on the findings of this research, 'philosophy' and 'services' mentioned by the IBD institutions did not indicate that a majority of them were moving towards IBD but on the contrary, towards a conventional perspective. This working paper supports the findings because the total number and percentage stated in this section exhibits the obvious compared to the general observation. Only 41 (46.1\%) IBD institutions in this research mentioned Islamic philosophy compared to 69 (77.5\%) institutions according to the general observation. Thus, for Islamic services only, 30 (33.7\%) institutions mentioned this component compared to 58 (65.2\%) institutions that did not. Following this finding, it could be said that all the IBD institutions in this working paper have deviated from the original objectives of IBD.

Table 3 shows the contents of the statements in detail as mentioned in the institution's mission statement. These statements indicate the criteria for a preferred Islamic-based analysis.

Table 3: Summary of the Institution's Mission Statements Based on Islamic-based Components

\begin{tabular}{ll}
\hline $\begin{array}{l}\text { Islamic-based } \\
\text { Components }\end{array}$ & Summary Statement \\
\hline Philosophy & - To realise the appreciation of Islam as the Ad-din \\
- To develop the ummah based on faith (akidah), syariah and \\
morals (akhlak) \\
- To enhance the socio-economic level of the ummah \\
- To safeguard the wisdom of the syariat \\
- To create prosperity among Muslims \\
- To form a distinguished Islamic teaching \\
- To form an Islamic institution that is ideal and outstanding \\
- To form an individual or society that upholds Islamic \\
- teachings \\
- To generate the development of the ummah based on \\
- Managing Islamic affairs \\
- Integrating Islamic values \\
- To develop the relationship between worldly and heavenly \\
- Management based on the al-Quran and as-Sunnah \\
Educate Muslims
\end{tabular}




\begin{tabular}{|c|c|}
\hline & $\begin{array}{l}\text { - Solving Islamic financial matters } \\
\text { - Islamic law }\end{array}$ \\
\hline Client & $\begin{array}{l}\text { - To lead Muslims } \\
\text { - To develop the ummah's personality } \\
\text { - To create prosperity among Muslims } \\
\text { - To create professional religious preachers } \\
\text { - To instil the compulsory nature of zakat onto Muslims } \\
\text { - Justice for the Muslim community }\end{array}$ \\
\hline Services & $\begin{array}{l}\text { - Quality services aimed at realising the appreciation of Islam } \\
\text { - } \text { Aims to educate and lead Muslims } \\
\text { - To enhance the socio-economic level of the Islamic } \\
\text { institution's ummah through good governance } \\
\text { - Excellent service in the management of fatwa and syarak } \\
\text { - Manage matters pertaining to advice, fatwa, falak, syarie } \\
\text { - To form a society that is knowledgeable, practices the } \\
\text { - } \text { religion and is of high moral standards } \\
\text { - } \text { - To channe and develop wakaf and baitulmal property in an } \\
\text { - Responsible for safeguarding Islam's sanctity } \\
\text { - To safeguard the prestige of Malay customs and law based } \\
\text { - } \text { on Islam modify financial solutions in line with the syariat } \\
\text { - To manage zakat funds in a fair, efficient, transparent and } \\
\text { - } \text { effective manner } \\
\text { - Tervices rendered to Muslims with full integrity and } \\
\text { professionalism }\end{array}$ \\
\hline Market & $\begin{array}{l}\text { - A famous Islamic institution at the international level } \\
\text { - For the local Muslims } \\
\text { - An outstanding institution in Malaysia }\end{array}$ \\
\hline Technology & $\begin{array}{l}\text { - Information technology development from an Islamic } \\
\text { management aspect } \\
\text { - Using the latest technology and services based on the al- } \\
\text { Quran and as-Sunnah. }\end{array}$ \\
\hline Profit & $\begin{array}{l}\text { - Finance based on the syarak and fairness } \\
\text { - The ummah's socio-economy through wakaf, zakat, mal } \\
\text { and hajj } \\
\text { - To expand the ummah's economy }\end{array}$ \\
\hline
\end{tabular}




\begin{tabular}{ll}
\hline - & To improve the socio-economic level of the ummah \\
\hline Image & - The Islamic institution as a famous tourist centre at the \\
& international level \\
- & To safeguard the syariat's prowess \\
\hline Employee & A vibrant Muslim corporate management \\
- Human Resources development
\end{tabular}

Generally, it could be concluded that 'organizational purpose' (direction), 'philosophy' and 'services' have become the focus and objective of IBD institutions. Nevertheless, all types of components in the analysis were obtained from conventional researchers. Therefore, it was found that the type of components listed were more towards the physical aspects only. Thus, in IBD, the physical and spiritual aspects are deemed important for an IBD institution in order to achieve the eventual 'organizational purpose' (direction) and objectives.

\section{Conclusion}

All in all, the aim and direction of IBD institutions in this study do not lead to the aim and direction of IBD. By contrast, the aim and direction cater more for the aim and direction of conventional development. The main focus of these institutions is more inclined to the conventional philosophy and service. This is because IBD has given more stress towards physical, rather than spiritual aspects. This is seen to be less suitable for institutions with Islamic orientation. Additionally, the mission statement is an important statement that reflects on the values and priorities of the organization (David, 1993:10).

\section{References}

Azizi \& Hossenabadi, V. (2014). A content analysis of the mission statements of Iran, Turkey, India and United States pharmaceutical companies. Journal of management and marketing, XII(1).

David, F. R. (1993). Strategic management 4ed. New York: MacMillan Publishing Company.

David, F. R. (2011). Strategic management: Concept and cases (13th ed). New Jersey: Pearson Education.

David, R. D. (2003). Strategic management: Concept and cases. New Jersey: Prentice Hall. David, R. D. (2006). Strategic management: Concept. New Jersey: Pearson Prentice Hall. 
Gamble, J. E., Peteraf, M. A. \& Thompson, J. A. A. (2016). Essentials of strategic management: The quest for competitive advantage. New York: McGraw Hill Education.

Hanson, D., Dowling, D., Hitt, M. A., Ireland, D. R. \& Hoskisson, R. E. (2008). Strategic management: Competitivess and globalization. Melbourne: Cengage Learning Australia.

Hashim, M. K. (2008). Strategic management: Text \& cases (second edition). Malaysia: Thomson Learning.

Jaradat, M. A. (2018). Black-Scholes Models with Inherited Time and Price Memory, International Journal of Academic Research in Accounting, Finance and Management Sciences 8 (4): 177-182.

JAWHAR. (2018). Mission. Retrieved from http://www.jawhar.gov. my/en/profil-jabatan/mengenai-jawhar/visi-misi-objektif-jabatan.

Jimale, D. (2012). Makna falsafah menurut Al-Kindi. Retrieved from http://ilmufalsafah.blogspot. com.

Majlis Agama Islam Selangor (MAIS) (2018). Mission. Retrieved from http://www.mais.gov.my/ info-mais/profil-korporat/visi-misi-objektif-strategi-dan-motto.

Manan, M. Z. A., Kasan, H. \& Bahall, M. Z. (2013). Pembangunan Islam di Malaysia. Retrieved from http://www.Islam.gov.my/enpembangunanislamdiMalaysia.

Manda, G. (2013). The importance of customer service to the organization. Retrieved from http://www.ehow.com/about6505645important-customer-service-organizational.html.

Mavridis, S., \& Mouratidou, S. (2019). Living in refugee camps in northern Greece. Multilingual Academic Journal of Education and Social Sciences, 7(1), 29-51.

Moin, M. F., Ali, A. \& Khan, A. N. (2012). An analysis of mission statement of Pakistani commercial (Scheduled) banks using a nine points scale approach of Fred R. David. Journal of Contemporary Research in Business, 4(2).

Omar, W. (1996). Pengurusan Islam abad ke-21: Revolusi pengurusan untuk keunggulan sektor awam dan korporat. Kuala Lumpur: Utusan Publications \& Distributors.

Rothaermel, F. T. (2015). Strategic management 2e. New York: McGraw Hill Education.

Strong, C. (1997). The question we continue to ask: How do organizations define their mission? Journal of Marketing Practice Applied Marketing Science, 3(4) 268283.

\section{Acknowledgement}

This research work is supported by Universiti Sains Malaysia (USM) under USM Bridging Grant (Reference No: 304 / CISDEV / 6316257) Titled the Biopsycosocial-Spiritual Dimension in Wellbeing Management among Female Staff in Islamic Institutions.

\section{Corresponding Author:}

Fadzila Azni Ahmad

Centre for Islamic Development Management Studies (ISDEV), Universiti Sains Malaysia, Malaysia E-mail: sukainah@usm.my

Address: Centre for Islamic Development Management Studies (ISDEV), Universiti Sains Malaysia, 11800 USM, Penang, Malaysia 